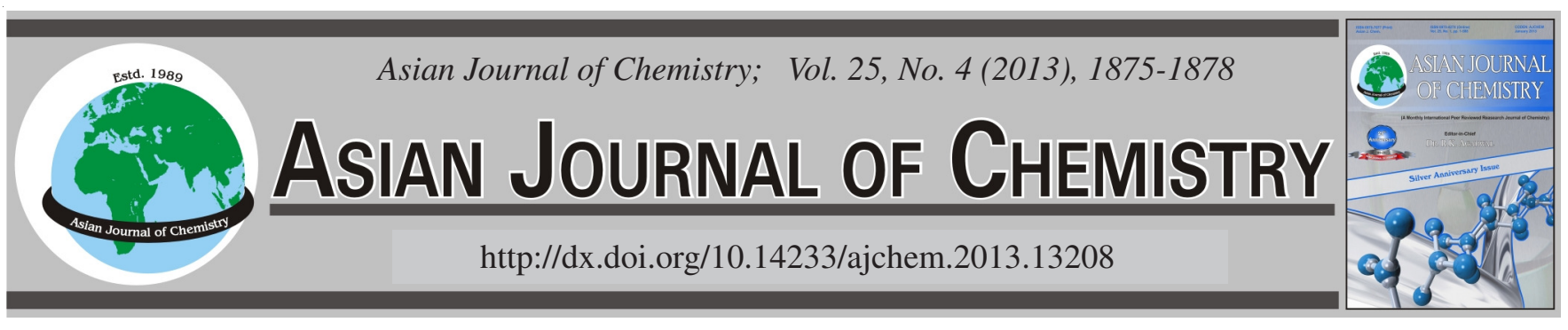

\title{
Antioxidative Coumarins from the Roots of Ferulago subvelutina
}

\author{
M. NASERI ${ }^{1}$, H.R. MonSEF-Esfehani ${ }^{1}$, S. SAEIDnia ${ }^{2}$, D. DASTAN ${ }^{3}$ and A.R. Gohari ${ }^{2, *}$
}

\begin{abstract}
${ }^{1}$ Department of Pharmacognosy, Faculty of Pharmacy, Tehran University of Medical Sciences, Tehran, Iran
${ }^{2}$ Medicinal Plants Research Center, Faculty of Pharmacy, Tehran University of Medical Sciences, Tehran, Iran

${ }^{3}$ Department of Phytochemistry, Medicinal Plants and Drugs Research Institute, Shahid Beheshti University, G.C., Evin, Tehran, Iran
\end{abstract}

*Corresponding author: Tel/Fax: +98 21 64122330; E-mail: goharii_a@tums.ac.ir

(Received: 8 December 2011;

Accepted: 5 October 2012)

AJC-12240

\begin{abstract}
From the ethyl acetate extract of the roots of Ferulago subvelutina (Apiaceae) six coumarins, osthol (1), oxypeucedanin (2), xanthotoxin (3), isoimperatorin (4), oxypeucedanin hydrate (5), meranzine hydrate (6) and one sterol, $\beta$-sitosteryl linoleate (7), were isolated by silica gel column chromatography and identified by spectroscopic methods. Antioxidant activities of the isolated compounds were tested by the DPPH radical scavenging assay. Compounds exhibited moderate antioxidant activities. DPPH scavenging abilities of compounds were lower than that of synthetic antioxidant tert-butyl hydroxytoluene $(\mathrm{BHT})\left(\mathrm{IC}_{50}=27 \mu \mathrm{g} / \mathrm{mL}\right)$ in the order BHT $>$ oxypeucedanin hydrate $>$ meranzin hydrate $>$ oxypeucedanin $>$ isoimperaturin $>$ xanthotoxin $>$ osthole.
\end{abstract}

Key Words: Ferulago subvelutina, Apiaceae, Coumarin, Osthol, Oxypeucedanin, Xanthotoxin, Isoimperatorin, Oxypeucedanin hydrate, Meranzine hydrate.

\section{INTRODUCTION}

The genus Ferulago (Apiaceae) consists of about 40 species. Five species of which are exclusively growing in the north-east and central parts of Iran including $F$. subvelutina, F. carduchorum, F. contracta, F. phialocarpa and F. trifida. Other species are growing abundantly in central Asia ${ }^{1}$. There are some evidences that Ferulago, Ferula and Prangos species have been used in folk medicine for their sedative, tonic, digestive, aphrodisiac properties and in the treatment of intestinal worms and hemorrhoid in different regions of Turkey. In addition, some of Ferulago species have been used in folk medicines against ulcers, snakebite, as well as headache and spleen disorders ${ }^{2-4}$. F. subvelutina Rech. F., a perennial herbaceous plant, grows widely in the north-east and central parts of Iran ${ }^{1}$.

A literature review shows that there are a few studies on phytochemical analysis of $F$. subvelutina. The essential oil of the aerial parts of $F$. subvelutina has been reported to contain 36 volatile compounds. Limonene (27.5\%), $\alpha$-phellandren $(23.1 \%)$ and $\alpha$-pinene $(13.3 \%)$ were major components. The essential oil showed antimicrobial activity against three species of Salmonella, Shigella flexneri and E. coli ${ }^{5}$. In this study, we report the isolation and identification of the main constituents of the ethyl acetate extract of the roots of $F$. subvelutina and antioxidant activities of the isolated compounds were tested by the DPPH radical scavenging assay which has not been previously reported.

\section{EXPERIMENTAL}

${ }^{1} \mathrm{H}$ and ${ }^{13} \mathrm{C}$ NMR spectra were recorded on a Brucker Avance 500 DRX spectrometer ${ }^{\circledR}$ with tetramethylsilane as an internal standard and chemical shifts are given in $\delta(\mathrm{ppm})$. Multiple-pulse experiments (HSQC, HMBC and H-H COSY) were performed using the standard Bruker ${ }^{\circledR}$ programs. Silicagel $60 \mathrm{~F}_{254}$ and Silicagel $60 \mathrm{RP}-18 \mathrm{~F}_{254} \mathrm{~S}$ pre-coated plates (Merck®) were used for TLC. The spots were detected by spraying with anisaldehyde- $\mathrm{H}_{2} \mathrm{SO}_{4}$ reagent followed by heating.

The roots of Ferulago subvelutina Rech. F. were collected in June 2009 from north-east of Iran, Khorasan province, Esfarayen, Rouein, $1650 \mathrm{~m}$ height. The plant was identified by Mr. Y. Ajani. A voucher specimen (No. 246 ACECR) has been deposited at the Herbarium of Complex of Academic Center for Educational and Cultural Research, Tehran, Iran.

Isolation process: The milled roots of $F$. subvelutina $(2500 \mathrm{~g})$ was extracted in ethyl acetate by percolation method at room temperature three times, each for $48 \mathrm{~h}$. Obtained extract was concentrated by rotary-evaporator, dried by freeze drier and preserved in refrigerator. The ethyl acetate extract (97 g) was subjected to silicagel column chromatography (CC). The column was eluted by different gradients of hexanechloroform, chloroform, chloroform-ethyl acetate, respectively, to yield 13 fractions (A-M). The compound $\mathbf{1}$ was isolated from the fraction $\mathrm{B}$ and crystallized as a pure compound. The 
fraction D (4.8 g) was submitted to silica gel CC with chloroform: ethyl-acetate (9:1) and ethyl-acetate to give seven fractions $\left(D_{1}-D_{7}\right)$. The fraction $D_{5}$ was crystallized as compound 2. The fraction $\mathrm{D}_{4}$ was subjected to sephadex $\mathrm{LH}_{20} \mathrm{CC}$ with methanol: chloroform $(7: 3)$ to obtain four fractions $\left(\mathrm{D}_{41}-\mathrm{D}_{44}\right)$. The fraction $\mathrm{D}_{43}$ was precipitated as needle crystals (compound 3, $72 \mathrm{mg}$ ). The fraction $\mathrm{D}_{2}$ was loaded on sephadex $\mathrm{LH}_{20} \mathrm{CC}$ and eluted by methanol:chloroform (8:2) to result five fractions $\left(\mathrm{D}_{21}-\mathrm{D}_{25}\right)$. The fraction $\mathrm{D}_{23}$ was pure (compound $4,19 \mathrm{mg}$ ). The fraction $\mathrm{H}$ was submitted to silica gel $\mathrm{CC}$ with ethyl acetate and ethyl acetate:methanol (9:1), respectively, to obtain eight fractions. The fraction $\mathrm{H}_{5}(637 \mathrm{mg})$ was compound 5. The fraction $\mathrm{H}_{7}$ was subjected to silica gel CC connected to MPLC apparatus resulted in isolation of five fractions, of which fraction $\mathrm{H}_{73}$ was pure (compound 6). The fraction A subjected to silica gel CC with hexane: chloroform (7:3), chloroform and chloroform:ethyl acetate (1:1), respectively. Among the eight obtained fractions, the fraction $\mathrm{A}_{2}$ was pure (compound 7, $162 \mathrm{mg}$ ).

Free radical scavenging activity: Free radical scavenging activity was evaluated by measuring the scavenging activity of the compounds in the solution of 2,2-diphenyl-1picrylhydrazyl (DPPH). One milliliter of DPPH solution (500 $\mu \mathrm{M}$ ) in methanol was thoroughly mixed with an equal volume of the test solution at various concentrations and kept in the dark for $0.5 \mathrm{~h}$. The absorbance of the solutions, including a blank (without sample) and a positive control (BHT, tertbutylated hydroxyltoluene), was read at $517 \mathrm{~nm}$ after $1 \mathrm{~h}$ incubation without light at room temperature on a Shimadzu UV-2100 spectrophotometer. Each sample assay was carried out in triplicate and the data presented as a mean of the three values. A decrease in absorbance of DPPH solution indicates the increase in DPPH radical scavenging activity. The values were calculated as a percentage using the following formula:

DPPH \% radical scavenging = $\left[\frac{\text { (Absorbance of blank - Absorbance of sample) }}{\text { Absorbance of blank }}\right] \times 100$

Antioxidant activities of the compounds were tested by the DPPH radical scavenging assay. The effect of antioxidant on DPPH radical scavenging was thought to be due to their radical scavenging activity. When a solution of DPPH is mixed with that of a substance, this gives rise to the reduced form diphenylpicrylhydrazyl (non radical) with the loss of this violet colour ${ }^{6}$.

\section{RESULTS AND DISCUSSION}

From the ethyl acetate extract of the roots of $F$. subvelutina, six coumarins, osthol $(\mathbf{1})^{7}$, oxypeucedanin $(\mathbf{2})^{8}$, xanthotoxin $(\mathbf{3})^{9}$, isoimperatorin $(\mathbf{4})^{9}$, oxypeucedanin hydrate $(\mathbf{5})^{10}$, meranzine hydrate $(\mathbf{6})^{11}$ and one sterol, $\beta$-sitosteryl linoleate $(7)^{12}$, were isolated by silica gel column chromatography and identified by comparison of their spectral data $\left({ }^{1} \mathrm{H} \mathrm{NMR},{ }^{13} \mathrm{C}\right.$ NMR) with those reported in the literature. The NMR data of the compounds 1-6 have been summarized in Tables 1-3. The structures of the isolated compounds are shown in the Fig. 1.

$\boldsymbol{\beta}$-Sitosteryl linoleate (7): ${ }^{1} \mathrm{H}$ NMR $\left(500 \mathrm{MHz}, \mathrm{CDCl}_{3}\right.$ ), $\delta$ H: 5.36 (5H, m, H-6, H-9', H-10', H-12', H-13'), 4.63 (1H, m, H-3), 1.03 (3H, s, Me-19), 0.93 (3H, d, $J=6.5 \mathrm{~Hz}, \mathrm{Me}-$ 21), 0.88 (3H, m, Me-18'), 0.84 (6H, m, Me-26 and Me-29), $0.82(3 \mathrm{H}, \mathrm{d}, J=6.6 \mathrm{~Hz}, \mathrm{Me}-27), 0.69(3 \mathrm{H}, \mathrm{s}, \mathrm{Me}-18) .{ }^{13} \mathrm{C}$ NMR (125 MHz, $\mathrm{CDCl}_{3}$ ), $\delta \mathrm{C}: 37.0$ (C-1), 27.8 (C-2), 73.7 (C-3), 38.3 (C-4), 139.7 (C-5), 122.6 (C-6), 31.8 (C-7), 31.9

TABLE-1

${ }^{1} \mathrm{H}$ NMR DATA OF THE COMPOUNDS 1, 3 AND 6 ( $\delta$ VALUES: ppm, $\mathrm{CDCl}_{3}$ )

\begin{tabular}{cccc}
\hline Carbon & $\mathbf{1}$ & $\mathbf{3}$ & $\mathbf{6}$ \\
\hline 3 & $6.18(\mathrm{~d}, J=9.4 \mathrm{~Hz}, 1 \mathrm{H})$ & $6.37(\mathrm{~d}, J=9.5 \mathrm{~Hz}, 1 \mathrm{H})$ & $6.23(\mathrm{~d}, J=9.5 \mathrm{~Hz}, 1 \mathrm{H})$ \\
4 & $7.57(\mathrm{~d}, J=9.4 \mathrm{~Hz}, 1 \mathrm{H})$ & $7.77(\mathrm{~d}, J=9.5 \mathrm{~Hz}, 1 \mathrm{H})$ & $7.63(\mathrm{~d}, J=9.5 \mathrm{~Hz}, 1 \mathrm{H})$ \\
5 & $7.25(\mathrm{~d}, J=8.5 \mathrm{~Hz}, 1 \mathrm{H})$ & $7.35(\mathrm{~s}, 1 \mathrm{H})$ & $6.34(\mathrm{~d}, J=8.5 \mathrm{~Hz}, 1 \mathrm{H})$ \\
6 & $6.80(\mathrm{~d}, J=8.5 \mathrm{~Hz}, 1 \mathrm{H})$ & - & $2.99(\mathrm{dd}, J=14,10 \mathrm{~Hz}, 1 \mathrm{H})$ \\
$1^{\prime}$ & $3.50(\mathrm{~d}, J=7 \mathrm{~Hz}, 2 \mathrm{H})$ & - & $3.08(\mathrm{dd}, J=14,2.5 \mathrm{~Hz}, 1 \mathrm{H})$ \\
$2^{\prime}$ & $5.20(\mathrm{t}, J=7 \mathrm{~Hz}, 1 \mathrm{H})$ & $7.69(\mathrm{~d}, J=2.2 \mathrm{~Hz}, 1 \mathrm{H})$ & $3.62(\mathrm{dd}, J=10,2.5 \mathrm{~Hz}, 1 \mathrm{H})$ \\
$3^{\prime}$ & - & $6.82(\mathrm{~d}, J=2.2 \mathrm{~Hz}, 1 \mathrm{H})$ & - \\
$4^{\prime}$ & $1.64(\mathrm{~s}, 3 \mathrm{H})$ & - & $1.32(\mathrm{~s}, 3 \mathrm{H})$ \\
$5^{\prime}$ & $1.81(\mathrm{~s}, 3 \mathrm{H})$ & - & $1.33(\mathrm{~s}, 3 \mathrm{H})$ \\
$\mathrm{OCH}_{3}$ & $3.89(\mathrm{~s}, 3 \mathrm{H})$ & $4.28(\mathrm{~s}, 3 \mathrm{H})$ & $3.92(\mathrm{~s}, 3 \mathrm{H})$ \\
\hline
\end{tabular}

TABLE-2

${ }^{1} \mathrm{H}$ NMR DATA OF THE COMPOUNDS 2, 4 AND 5 ( $\delta$ VALUES: ppm, $\mathrm{CDCl}_{3}$ )

\begin{tabular}{clll}
\hline Carbon & \multicolumn{1}{c}{$\mathbf{2}$} & \multicolumn{1}{c}{$\mathbf{4}$} & \multicolumn{1}{c}{$\mathbf{5}$} \\
\hline 3 & $6.32(\mathrm{~d}, J=9.7 \mathrm{~Hz}, 1 \mathrm{H})$ & $6.26(\mathrm{~d}, J=9.7 \mathrm{~Hz}, 1 \mathrm{H})$ & $6.22(\mathrm{~d}, J=9.5 \mathrm{~Hz}, 1 \mathrm{H})$ \\
4 & $8.20(\mathrm{~d}, J=9.7 \mathrm{~Hz}, 1 \mathrm{H})$ & $8.15(\mathrm{~d}, J=9.7 \mathrm{~Hz}, 1 \mathrm{H})$ & $8.14(\mathrm{~d}, J=9.5 \mathrm{~Hz}, 1 \mathrm{H})$ \\
8 & $7.20(\mathrm{~s}, 1 \mathrm{H})$ & $7.14(\mathrm{~s}, 1 \mathrm{H})$ & $7.08(\mathrm{~s}, 1 \mathrm{H})$ \\
$2^{\prime}$ & $7.61(\mathrm{~s}, 1 \mathrm{H})$ & $7.58(\mathrm{~d}, J=2.3 \mathrm{~Hz}, 1 \mathrm{H})$ & $7.58(\mathrm{~d}, J=2.5 \mathrm{~Hz}, 1 \mathrm{H})$ \\
$3^{\prime}$ & $6.95(\mathrm{~s}, 1 \mathrm{H})$ & $6.95(\mathrm{~d}, J=2.3 \mathrm{~Hz}, 1 \mathrm{H})$ & $6.97(\mathrm{~d}, J=2.5 \mathrm{~Hz}, 1 \mathrm{H})$ \\
$1^{\prime \prime}$ & $4.44(\mathrm{dd}, J=10.3,6.4 \mathrm{~Hz}, 1 \mathrm{H})$ & $4.91(\mathrm{~d}, J=6.8 \mathrm{~Hz}, 2 \mathrm{H})$ & $4.43(\mathrm{dd}, J=9.5,7.5 \mathrm{~Hz}, 1 \mathrm{H})$ \\
$2^{\prime \prime}$ & $4.59(\mathrm{dd}, J=10.3,6.6 \mathrm{~Hz}, 1 \mathrm{H})$ & & $4.54(\mathrm{dd}, J=9.5,3 \mathrm{~Hz}, 1 \mathrm{H})$ \\
$4^{\prime \prime}$ & $3.23(\mathrm{~m}, 1 \mathrm{H})$ & $5.53(\mathrm{t}, J=6.8 \mathrm{~Hz}, 1 \mathrm{H})$ & $3.90(\mathrm{dd}, J=7.5,3 \mathrm{~Hz}, 1 \mathrm{H})$ \\
$5^{\prime \prime}$ & $1.33(\mathrm{~s}, 3 \mathrm{H})$ & $1.69(\mathrm{~s}, 3 \mathrm{H})$ & $1.35(\mathrm{~s}, 3 \mathrm{H})$ \\
\hline
\end{tabular}




\begin{tabular}{|c|c|c|c|c|c|c|}
\hline \multicolumn{7}{|c|}{$\begin{array}{c}\text { TABLE-3 } \\
{ }^{13} \mathrm{C} \text { NMR CHEMICAL SHIFTS OF THE COUMARINS } \\
\text { ISOLATED FROM } F \text {. subvelutina }\left(\delta_{\mathrm{c}}: \mathrm{ppm}, \mathrm{CDCl}_{3}\right)\end{array}$} \\
\hline Carbon & 1 & 2 & 3 & 4 & 5 & 6 \\
\hline 2 & 161.2 & 161.0 & 160.5 & 161.3 & 161.3 & 161.3 \\
\hline 3 & 112.7 & 113.2 & 114.7 & 112.5 & 112.8 & 113.0 \\
\hline 4 & 143.7 & 139.0 & 144.3 & 139.6 & 139.2 & 144.0 \\
\hline 5 & 126.1 & 148.4 & 112.9 & 148.9 & 148.5 & 127.0 \\
\hline 6 & 107.2 & 114.2 & 126.1 & 114.2 & 114.1 & 107.4 \\
\hline 7 & 160.1 & 158.3 & 147.6 & 158.1 & 158.0 & 160.5 \\
\hline 8 & 117.7 & 94.9 & 132.8 & 94.2 & 94.6 & 115.7 \\
\hline $4 a$ & 112.8 & 107.5 & 116.5 & 107.3 & 107.1 & 113.1 \\
\hline $8 a$ & 152.7 & 152.6 & 143.0 & 152.6 & 152.4 & 153.4 \\
\hline $1^{\prime}$ & 21.8 & - & - & - & - & 26.1 \\
\hline $2^{\prime}$ & 121.0 & 145.3 & 146.6 & 144.9 & 145.2 & 78.3 \\
\hline $3^{\prime}$ & 132.4 & 104.5 & 106.7 & 105.0 & 104.8 & 73.1 \\
\hline $4^{\prime}$ & 25.7 & - & - & - & - & 24.0 \\
\hline $5^{\prime}$ & 17.8 & - & - & - & - & 25.6 \\
\hline $1 "$ & - & 72.3 & - & 69.7 & 71.7 & - \\
\hline $2^{\prime \prime}$ & - & 61.1 & - & 119.1 & 74.4 & - \\
\hline 3" & - & 58.3 & - & 139.8 & 76.5 & - \\
\hline 4" & - & 19.0 & - & 18.2 & 26.6 & - \\
\hline $5^{\prime \prime}$ & - & 24.6 & - & 25.8 & 25.1 & - \\
\hline $\mathrm{OCH}_{3}$ & 55.9 & - & 61.3 & - & - & 56.2 \\
\hline
\end{tabular}<smiles></smiles>

Oxypeucedanin hydrate (5)

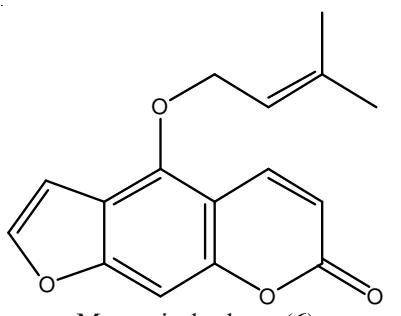

Meranzin hydrate (6)

Fig. 1. Structures of the isolated compounds from $F$. subvelutina

(C-8), 50.0 (C-9), 36.6 (C-10), 21.0 (C-11), 39.7 (C-12), 42.3 (C-13), 56.7 (C-14), 24.3 (C-15), 28.2 (C-16), 56.0 (C-17), 11.8 (C-18), 19.3 (C-19), 36.1 (C-20), 18.8 (C-21), 33.9 (C-22), 26.1 (C-23), 45.8 (C-24), 29.1 (C-25), 19.0 (C-26), 19.8 (C-27), 23.0 (C-28), 12.0 (C-29), 173.3 (C-1'), 34.7 (C-2'), 25.0 (C-3'), 29.1 (C-4'), 29.3 (C-5'), 29.6 (C-6'), 29.6 (C-7'), $27.2\left(\mathrm{C}-8^{\prime}\right), 130.1\left(\mathrm{C}^{\prime} 9^{\prime}\right), 127.9$ (C-10'), $25.6\left(\mathrm{C}-11^{\prime}\right)$, 128.0 (C-12'), 130.2 (C-13'), 27.2 (C-14'), 29.3 (C-15'), 31.5 (C-16'), 22.5 (C-17'), 14.1 (C-18').

The literature review shows that the coumarins $1,2,4$ and $\mathbf{5}$ have been previously reported from various Ferulago species. A summary of the widespread coumarins within Ferulago species is shown in Table-4. Two other isolated coumarins $\mathbf{3}$ and $\mathbf{6}$ have not been reported from this genus until now, so that this is the first report for presence of xanthotoxin (3) and meranzin hydrate (6) in Ferulago.

\begin{tabular}{|c|c|c|c|}
\hline \multicolumn{4}{|c|}{$\begin{array}{c}\text { TABLE-4 } \\
\text { DISTRIBUTION OF THE ISOLATED } \\
\text { COUMARINS WITHIN FERULAGO SPECIES }\end{array}$} \\
\hline Compound & Plant & Source & Ref. \\
\hline \multirow{4}{*}{ Osthol } & F. brachyloba & Roots & 13 \\
\hline & F. campestris & Roots & 14 \\
\hline & F. capillaries & Roots & 13 \\
\hline & F. turcomanica & Roots & 15 \\
\hline \multirow{8}{*}{ Oxypeucedanin } & F. bernardii & Aerial parts & 16 \\
\hline & F. brachyloba & Roots & 13 \\
\hline & F. capillaries & Aerial parts and roots & 13 \\
\hline & $F$. granatensis & Roots & 17 \\
\hline & F. meoides & Umbels & 18 \\
\hline & F. platycarpa & Roots & 19 \\
\hline & F. sylvatica & Roots & 20 \\
\hline & F. turcomanica & Roots & 15 \\
\hline \multirow{5}{*}{ Isoimperatorin } & F. capillaries & Aerial parts and roots & 13 \\
\hline & F. grandatensis & Umbels & 17 \\
\hline & F. meoides & Roots & 18 \\
\hline & F. sylvatica & Roots & 20 \\
\hline & F. turcomanica & Roots & 15 \\
\hline \multirow{5}{*}{$\begin{array}{c}\text { Oxypeucedanin } \\
\text { hydrate }\end{array}$} & F. brachyloba & Roots & 13 \\
\hline & F. capillaries & Roots & 13 \\
\hline & F. meoides & Umbels & 18 \\
\hline & F. sylvatica & Roots & 20 \\
\hline & F. turcomanica & Roots & 15 \\
\hline
\end{tabular}


Free radical scavenging properties of the compounds are presented in Table-5. Lower $\mathrm{IC}_{50}$ value indicates higher antioxidant activity. All the tested compounds exhibited moderate antioxidant activities. DPPH scavenging abilities of compounds were lower than that of synthetic antioxidant BHT $\left(\mathrm{IC}_{50}=27\right.$ $\mu \mathrm{g} / \mathrm{mL})$. In this study, DPPH radical scavenging activity of the test samples was in the order BHT > oxypeucedanin hydrate $>$ meranzin hydrate $>$ oxypeucedanin $>$ isoimperaturin $>$ xanthotoxin $>$ osthole. As it is shown in Table-5, peucedanin hydrate and meranzin hydrate presented higher antioxidant activity than the other isolated coumarins.

\begin{tabular}{lc}
\multicolumn{2}{c}{ TABLE-5 } \\
\multicolumn{2}{c}{ ANTIOXIDATIVE ACTIVITIES OF THE ISOLATED } \\
\multicolumn{1}{c}{ COMPOUNDS AGAINST DPPH $\left(\mathrm{IC}_{50}\right)$} \\
\hline \multicolumn{1}{c}{ Compound } & ${\text { DPPH } \mathrm{IC}_{50}(\mu \mathrm{g} / \mathrm{mL})}$ \\
\hline Oxypeucedanin hydrate & 160 \\
Meranzin hydrate & 180 \\
Osthole & 210 \\
Oxypeucedanin & 217 \\
Isoimperaturin & 245 \\
Xanthotoxin & 270 \\
BHT & 27 \\
\hline
\end{tabular}

\section{Conclusion}

The result of this study revealed that $F$. subvelutina contains various coumarins as the main components of the roots, which presented diverse antioxidative activity. Phytochemical investigation on the arial parts of this species is suggested for future studies.

\section{ACKNOWLEDGEMENTS}

The authors thank Mr. Yousef Ajani for his kind help in collection and identification of the plant. The authors wish to thank Miss. Mahdie Kurepaz-mahmoodabadi for kind collaboration in the laboratoy of Medicinal Plants Research Center, Tehran University of Medical Sciences.

\section{REFERENCES}

1. K.H. Rechinger, I.C. Hedge and J.M. Lamond, Flora Iranica, 162, 427 (1987).

2. A. Rustaiyan, S. Sedaghat, K. Larijani, M. Khossravi and S. Masoudi, J. Essent. Oil Res., 14, 447 (2002).

3. F. Sefidkon and R. Omidbaigi, J. Essent. Oil Bearing Plants, 7, 60 (2004).

4. S. Rezazadeh, D. Yazdani and S. Shahnazi, J. Med. Plants, 2, 49 (2003).

5. F. Chalabian, A. Monfared, K. Larijani and S. Saldoosi, J. Med. Aromat. Plants, 22, 146 (2006).

6. P. Molyneux, J. Sci. Technol., 26, 211 (2004).

7. P. Zhou, Y. Takaishi, H. Duan, B. Chen, G. Honda, M. Itoh, Y. Takeda, O.K. Kodzhimatov and K.H. Lee, Phytochemistry, 53, 689 (2000).

8. S. Harkar, T.K. Razdan and E.S. Waight, Phytochemistry, 23, 419 (1984).

9. T. Masuda, M. Takasugi and M. Anetai, Phytochemistry, 47, 13 (1998).

10. K. Ishihara, M. Fukutake, T. Asano, Y. Mizuhara, Y. Wakui, T. Yanagisawa, H. Kamei, S. Ohmori and M. Kitada, J. Chromatogr. B, 753, 309 (2001).

11. R. Dondon, P. Bourgeois and S. Fery-Forgues, Fitoterapia, 77, 129 (2006).

12. S. Hua, Y.S. Kim, E. Jung, J. Lim, K.S. Jung, M.O. Kim, J. Lee and D. Park, Biol. Pharm. Bull., 33, 1242 (2010).

13. B. Jimenez, M.C. Grande, J. Anaya and P. Torres, Phytochemistry, 53, 1025 (2000).

14. A. Basile, S. Sorbo, V. Spadaro, M. Bruno, A. Maggio, N. Faraone and S. Rosselli, Molecules, 14, 939 (2009).

15. S.V. Serkerov, A.A. Kagramanov and R.M. Abbasov, Chem. Nat. Comp., 12, 82 (1976).

16. F. Khalighi-Sigaroodi, A. Hadjiakhoondi, A. Shafiee, V.A. Mozaffarian, A.R. Shahverdi and S.H.R. Alavi, Daru, 14, 214 (2006).

17. T.J. De Pascal, B. Jimenez, B. Corrales and M. Grande, An. Quim., 75, 175 (1979).

18. I. Ognyanov and D. Bocheva, Planta Med., 17, 65 (1969).

19. E. Satir, S. Kilic and M. Coskun, Chem. Nat. Comp., 45, 872 (2009).

20. Y.E. Sklyar, V.B. Andrianova and M.G. Pimenov, Chem. Nat. Comp., 18, 448 (1982). 